\title{
Cloud on the Horizon: African Migration, Transnationalism, and Social Osmosis
}

\author{
JOSEPH J. BANGURA*
}

\begin{abstract}
This paper argues that the factors that induce transcontinental and intercontinental African migration are complex and cannot be reduced to simplistic generalizations. It states that Africa's transcontinental and transnational migratory phenomena from the medieval period to the post-modern era were a two-way street. While Africans migrated abroad, the continent has also continuously served as a magnet for migrants from other continents. Thus, despite the exaggerated portrayal of African migration to Europe and North America, the available data sources show that transcontinental and transnational African migration is microscopic compared to the global migratory trend.
\end{abstract}

\section{Introduction ${ }^{1}$}

T his paper argues that intercontinental and transnational African migration, especially in the modern era is minuscule relative to global migratory trends. It states that Africa's transcontinental and transnational migratory phenomena from the medieval period to the post-modern era were a two-way street. While Africans migrated to other continents, the continent has also continuously served as a magnet for migrants since $146 \mathrm{BC}$ when the Greeks and Romans invaded and annexed the territory that is part of modern Tunisia. In fact, between the $15^{\text {th }}$ and $19^{\text {th }}$ centuries, Africa became the site of one of the largest involuntary migrations in history. This event happened during the Atlantic Slave Trade which involved the forced transportation and transplantation of Africans to Europe and the Americas. In other words, the phenomenon of involuntary and voluntary migration has always been part of the fabric of Africa's historical development and political trajectory. ${ }^{2}$

On the basis of the above, the current trend of African migration can be attributed to colonial, neo-colonial and neoliberal policies adopted by European 
countries and the United States towards Africa since the mid-20 ${ }^{\text {th }}$ century. As a matter of fact, numerous scholars attribute Africa's post-independence economic and social malaise to colonialism. They argue that colonialism undermined and to some extent stifled Africa's organic progressive trajectory through the adoption of uncongenial colonial economic policies, persistent denigration and vitiation of the continent's entrenched value system including its sui generis historic democratic configurations. ${ }^{3}$ Expressed another way, the policies adopted and executed by the colonial authorities hampered the continents capacity and potential to embark on economic development commensurate with its heterogeneous cultural aptitude since independence. The consequences of these policies resulted in the creation of porous borders leading to ethnographic and avaricious conflicts between African countries, lack of industrialization, lack of sustainable governance structures and viable institutions, and the facilitation of venal practices among African elites. The impact of these colonial policies did not disappear at the onset of independence or in the post-independence period. As a matter of fact, the policies took a different turn in the form of neo-colonial policies that contributed to civil strife, economic degradation, proliferation of weak states, perpetuation of warlord culture resulting in the emergence of those thatAnders Themnér refers to as "warlord democrats" and poor governance. ${ }^{4}$

The paper is organized into two major sections. Section one situates African migration in historic terms and underlines the importance of the continent's complex and longstanding relationship with the West. It shows that African migration is not a recent phenomenon. It highlights that Africa, Europe, and the Americas have had an interactive relationship through migratory exchanges since the making of the Atlantic world in the $15^{\text {th }}$ century. ${ }^{5}$ It assesses Europe's colonial and neo-colonial relationship with Africa that ramped up transnational and transcontinental migrations. The second section which constitutes the conclusion analyzes the factors that instigate the current African migratory trend and patterns. Succinctly put, Africans, Europeans, and Americans have experienced and continue to experience transatlantic migration in a variety of ways and for multifarious reasons. It is clear that African migrants seeking asylum and refugee status in western Europe and the United States persistently face heavy headwinds with inflammatory renunciations regularly directed against them while their various contributions to their host countries are patently disregarded.

\section{Intracontinental African Migration in the Medieval and Early Modern Period}

Migration has always been a distinct feature of Africa's sociocultural traditions and customs; this is because Africans regularly moved from place to place 
within and outside the continent. In the pre-medieval and medieval period, the availability of abundant and unoccupied tracts of lands made people incessantly move from region to region in search of socioeconomic opportunities; some of these migratory activities resulted in populating new lands. The prosperous kingdoms and empires of western Sudan -Ghana, Mali, and Songhai- rose and fell due to factors such as migration, geographic advantage, ability to control communication and strategic trading routes, and dominance of the Gold trade among numerous others. Put another way, the vast and verdant nature of the savannah zone attracted lots of migrants from different regions that contributed to the establishment of some of the biggest empires in medieval Africa. Equally important is the fact that the movement of large populations contributed to the demise of these empires in addition to insecurity, internal rivalry, and invasion from external aggressors. The collapse of the western Sudanese empires resulted in the displacement of a substantial number of people who traveled across regions. The disintegration of other major kingdoms and their economic infrastructures also triggered mass movements of people across swaths of territories in the continent. ${ }^{6}$ Other causes of intracontinental migration included trade wars and power politics that comprised dictatorial heavy handedness and extraterritorial conflicts. These problems were exacerbated by Africa's early contact with Europeans and later the Americans.

It is worth noting that the relationship between Africa and Europe is historic and extensively intertwined since $146 \mathrm{BC}$ when the Greeks invaded what is today north Africa because of the region's strategic commercial position. Subsequently, the Roman Empire dislodged the Greeks and annexed the entire northern half of Africa that later came to be known as Roman Africa. However, Roman presence and influence eventually declined in northern Africa. The decline of Greek and Roman influence was met with Portugal's rise as a European power interested in marine adventures. Thus, Portugal became the first European nation to explore and locate coastal communities in sub-Saharan Africa in the $15^{\text {th }}$ century. In fact, the relationship between the two continents deepened when Portugal indubitably initiated a trade in human beings notoriously referred to as the Transatlantic Slave Trade.

The Transatlantic Slave Trade made slave raiding a regular economic venture of considerable proportion and it became the single-most economic phenome- 
Intra-African movements of people did not disappear with the end of colonial rule. In fact, mass intra-continental migration continued at a high intensity as a considerable number of people moved from inland regions to major and coastal cities in the postindependence period non that brought the tri-continents of Africa, Europe, and America together in a transcultural and macroeconomic alliance that transformed the rarely used Atlantic Ocean into a highway of transportation and commerce. Together, Africans, Europeans, and Americans became the primary makers of the Atlantic world which to some extent formed the anchor for the economic prosperity of British North America, Portuguese and Spanish south, and central America. As the Atlantic slave trade became a hyper lucrative

transaction, demands for slaves soared. The surge in demand for slaves led to the raiding of African villages, towns, cities, and poorly protected groups by powerful slave raiders. Ergo, slave raiding, and the slave trade became major sources of intracontinental and transnational migration. Africans were involuntarily shipped across two continents between the $15^{\text {th }}$ and $19^{\text {th }}$ centuries accompanied by hazardous consequences. It is plausible to argue that this forced migration of Africans to Europe and the Americas and the relationship that emerged between the three continents continue to influence contemporary migration of Africans to these continents. That is, the historic relationship cultivated and cemented by the peoples of the three continents through the Transatlantic Slave Trade and also during colonialism had a bearing on contemporary African migration to these continents. The millions of Africans transported to the Americas created an elastic connection between those who became known as African Americans and continental Africans. Some scholars argue that about twelve million Africans were forcefully transported to the Americas between the $15^{\text {th }}$ and $19^{\text {th }}$ centuries while others argue that about 20 million African slaves made the journey from Africa to the American continent. ${ }^{7}$

The eventual abolition of the slave trade and slavery was replaced by the establishment of a European colonial edifice that shaped the social, economic and political lives of Africans from the $19^{\text {th }}$ to the mid- $20^{\text {th }}$ century. With the imposition of colonial rule, Europeans forged a different relationship with Africa based on what has been famously referred to as "legitimate commerce" -a trading system that was based on selling and buying commodities in lieu of trading in human beings. Nonetheless, the policies adopted by European colonialists triggered largescale displacement and resettlement of Africans. Many displaced Africans traversed various regions and boundaries in search of greener pastures; i.e. they traveled to areas where cash crops, mineral resources, and infrastructural facilities existed. ${ }^{8}$ Clearly, colonialism heightened 


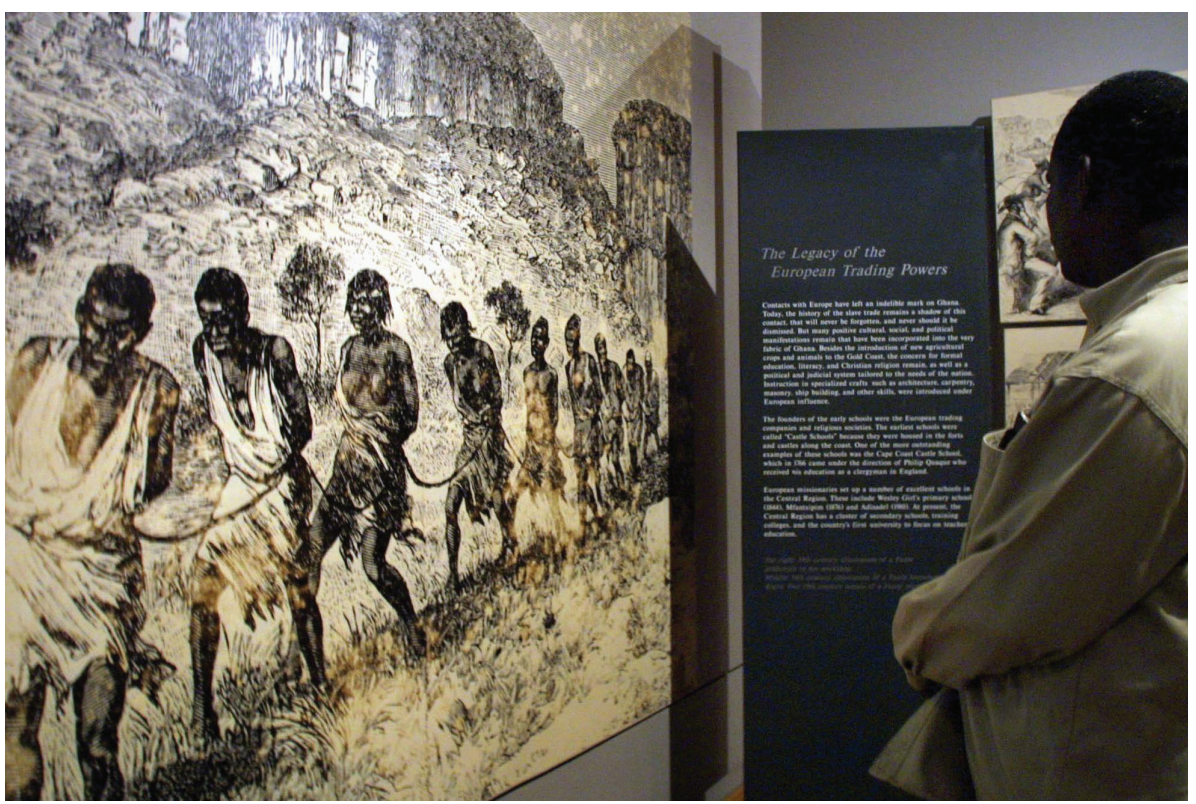

A man studies images of slavery in the Cape Coast Castle, Ghana, which bears mute testimony to centuries of tears, sweat, and torture as a result of the Swedish and British colonialism.

ISSOUF SANOGO / AFP / Getty Images

rural-urban migration both seasonally and permanently. ${ }^{9}$ Labor migration instigated a continuous largescale rural-rural and rural-urban migration, particularly in west Africa. This migration trend involved both intra-regional movements and inter-regional crossings from countries with scarce natural resources to countries with abundant and valuable natural resources. For example, migrant laborers traveled from Burkina Faso and Mali to Senegal, Ghana, Côte d'Ivoire, Nigeria, and Sierra Leone to work in the cocoa and coffee plantations and participate in mining diamonds. ${ }^{10}$ Other west Africans also migrated to central Africa to engage in the diamond trade. In Southern and Eastern Africa, the colonial authorities dislodged and displaced many of the indigenous population by establishing permanent European settlements and agro-economic infrastructures. The establishment of plantations and mining industries in these regions also became economic magnets that attracted a big wave of labor migrants from central and west Africa. Though such internal migration proved economically beneficial, it caused labor shortage in regions with limited natural resources. It also resulted in massive dispersal of people, which sometimes tore families apart and caused misery to those that found it impossible to relocate to resource rich regions. This deepened under-population and heightened overpopulation in various regions. Intra-African movements of people did not disappear with the end of colonial rule. In fact, mass intra-continental migration continued at a high intensity as a considerable number of people moved from inland regions to major and coastal cities in the post-independence period. The formation and establishment of regional organizations such as the Economic Community 
of West African States (ECOWAS), Southern African Development Community (SADC), East African Community (EAC) and the Common Market for Eastern and Southern Africa (COMESA) has facilitated mass intra-African migration by making great improvements in regional infrastructures. In addition, the policies adopted by these regional organizations, facilitated and enhanced regional migration trends. Some of the policies include visa waivers for residents of member countries and tariff free importation and exportation of goods from member states. Overall, these regional blocs account for over $2 / 3$ of the population of the African continent. One of the biggest regional blocs, ECOWAS, consists of 15 countries and has an estimated population of 340 million. ${ }^{11}$ Given the size of the population, intra-regional migration within ECOWAS is considerable. Analogously, the populations of SADC, EAC and COMESA account for over 500 million Africans. The total population estimate for SADC is 312 million, comprising 15 member states while the population estimates for EAC and COMESA are 168.5 and 492.5 million respectively. ${ }^{12}$ In sum, it is reasonable to argue that intra-regional African migration is greater than intercontinental African migration.

\section{Intercontinental African Migration, Transnationalism, and Social Osmosis}

Clearly, the convoluted historic relationship between Africa and Europe has resulted in thousands of Africans undertaking migratory adventures to reach the continent of their former colonialists and slave trade partners. In short, Europeans and Africans have experienced and continue to experience transatlantic migration in a variety of ways and for multifarious reasons. African migration to Europe and north Africa in particular during colonialism was limited and it largely involved students who sought undergraduate and graduate education on the one hand and students who needed vocational training on the other. However, since independence, the number of African migrants in Europe and North America sharply increased. As a matter of fact, from the 1950s through the 1980s African migration to Europe was shaped by colonialism and its attendant conjugations such as the imposition of European culture and languages on Africans. Put differently, African migrants from English-speaking countries (Anglophone Africans) primarily traveled to the United Kingdom, while French-speaking Africans (Francophone Africans) traveled to France and Belgium. Similarly, Africans colonized by Portugal with competence in Portuguese (Lusophone Africans) regularly migrated to Portugal, especially Angolans, Mozambicans, and Guinea Bissauans.

Though this migration trend held steady between the 1950s and 1980s, the trend changed as many African economies collapsed. Migration to Europe continued at an increased pace as Africans demanded jobs and better living 
conditions. Given the persistence of these demands and at the prompting of Western governments, especially after the demise of the Soviet Union, African states embarked on the process of democratization in the 1990s. The wave of democratization that swept the African continent led to increased political participation and the introduction of political pluralism in many countries. The democratic process kindled the hopes of many Africans as some of the repressive old guards were replaced with new regimes. But the new democratic dispensation triggered by the wave of democratization did not lead to better governance or economic prosperity. In consequence, the failure of the democratization

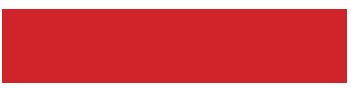

\section{By immigrating to the West, many African immigrants flee the social pressure caused by the absence of economic opportunities and upward mobility} process contributed to the outbreak of deadly conflicts in Liberia, Sierra Leone, Somalia, Rwanda, Cote d'Ivoire, Sudan, and the Democratic Republic of Congo. ${ }^{13}$ Thus, migration from many of these conflict-ridden states and other states that experienced economic meltdown spiked to immense proportion. African migration became diversified and lost its colonial streak as many immigrated to the United States, Canada, Australia, Japan, China, and European countries without colonial ties such as Spain, Germany, and the Netherlands. Akin to this, the composition of migrants consists of people with different skill sets, including both poorly and highly educated Africans.

As contemporary African migration to Europe, North America, Australia, and Asia surged, many factors influenced this trend. Pauline Ada Uwakeh and others argue that African migration has been influenced by "globalization of labor markets" and "mobility of highly skilled personnel." ${ }^{4}$ They also note that the "disequilibrium [caused] by colonialism" undermined the post-colonial African state. Closely related to this, they also blamed the Diversity Lottery Visa instituted by the U.S. government to increase immigration to the country. This scheme led to a huge wave of migration of Africans to the United States from the 1990s to the present day. The visa lottery system also resulted in increased migration of low-skilled Africans to the U.S. In spite of the inflammatory anti-immigrant rhetoric and activities, Africans continue to use the visa lottery system as an effective instrument to legally immigrate to the United States. Parallel to the above, Kane and Leedy emphasize "the push and pull" factors as one of the major causes that drive transnational and transcontinental African immigration. These factors include acute unemployment, high-levels of poverty, and unending social upheavals, among others. Thus, by immigrating to the West, many African immigrants flee the social pressure caused by the absence of economic opportunities and upward mobility. 


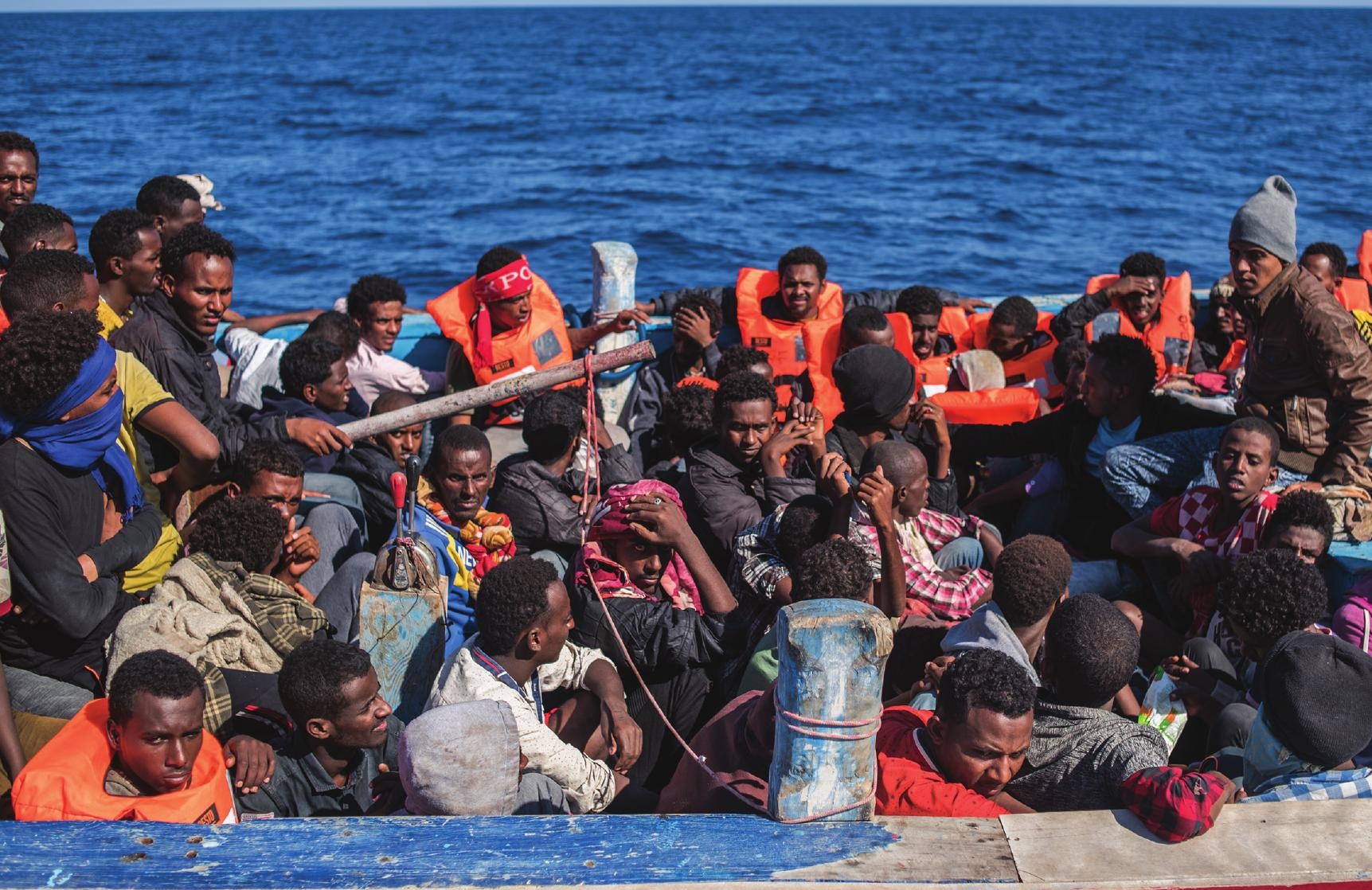

Migrants dangerously packed into a simple boat attempting

to make

the journey

across the

Mediterranean

Sea into Europe in November

2017.

SAMUEL NACAR LightRocket via Getty Images

With the formation of the European Union, which integrated the borders of Europe, many African immigrants strove to enter any European country to seek refugee status or asylum. In other words, though many Africans embarked on voluntary migration to continents other than Europe since 2015, the bulk of migrants have traveled to southern Europe, particularly Spain, Greece, and Italy. Data sources show that African migration to Spain reached 7,900 between January and July 2018 and a total of 10,050 African migrants entered Italy during the same period while an estimated 800 African migrants have traveled to Greece so far this year. ${ }^{15}$ In the same vein, about 1,600 African migrants are estimated to have died crossing the Mediterranean Sea. ${ }^{16}$

It is clear from the statistics above that though a sizeable number of migrants have traveled to Europe to seek asylum, interviews conducted by the author shows that the total number of migrants is relatively small. A five-page questionnaire that focused on the circumstances that prompted the interviewees to seek asylum in Europe, the nature of their journey to Europe, the conditions in the refugee camps, the attitude of citizens of host countries, social barriers experienced in host countries such as language, lack of employment opportunities, assimilation of host country's cultural values, and the desire of interviewees to return to their country of origin in the short, medium or long term was administered to participants or subjects. The process of selecting subjects for the interviews was random and dependent on the willingness of the subjects to agree to an interview. In some cases, the questionnaire was issued to the 


\section{Economic consideration was not the prima facie factor that instigated the wave of contemporary migration to southern Europe}

subjects to fill, especially those proficient in English. In situations where the subject was literate in another European language such as French, the services of interpreters were utilized. Finally, in cases where the subject spoke English but was unable or reluctant to fill out the questionnaire, the author used their responses to fill out the questionnaire. In all, 30 subjects were interviewed in Greece and Italy.

Though Kane, Leedy, Uwakeh, and others indicate that economic necessities triggered and continue to trigger transcontinental African migration to Europe, interviews conducted in Greece and Italy show that economic consideration was not the prima facie factor that instigated the wave of contemporary migration to southern Europe. The sample responses from the interviews indicate that migrants who traveled to Greece and Italy to seek asylum and refugee status did so for a variety of reasons such as politics, ethnic strife, sexual discrimination, and economic opportunism among others. An interview conducted with an African immigrant from Ethiopia referred to as "Interviewee A" left Ethiopia because of the political repression her family suffered under the government of the late Prime Minister Meles Zenawi. Born in Debr Zeyit, her father was a soldier in the army and her mother a retail entrepreneur. The interviewee's family became a frequent target of the government which perceived her father as disloyal and a dissident. A high school dropout that worked in menial jobs, the interviewee stressed that the political pressure her family suffered forced her to immigrate to Greece in 2003. Because of the tortuous nature of her journey, she made a number of stops on her way to Greece including a three year stop in Beirut, Lebanon. ${ }^{17}$ Determined to seek refugee status in Greece, the interviewee left Lebanon for Turkey where she was arrested and imprisoned for five months. Upon her release, she embarked on the perilous trans-Mediterranean journey via a boat to Greece where she applied for asylum. Faced with a raft of social problems such as a language barrier, racism and lack of money to survive, she joined forces with her would-be boyfriend and they both started a restaurant business. Two years after she applied for asylum, the Greek government granted her refugee status. Though a legal resident, with a fairly thriving restaurant business the interviewee hopes to return to Ethiopia in the near future.

Another interviewee, Victor Okarfo from eastern Nigeria who identified himself as an Igbo-speaker, immigrated to Greece because of insecurity pre- 
cipitated by inter-communal and inter-ethnic conflicts. Victor claimed to have suffered a unique form of "racism" in his native Nigeria because of his ethnic and regional identity. As a result of this experience, he decided to leave Nigeria for Greece in 2013 via Turkey where he stayed for 18 months. In 2015, Victor departed for the Greek island of Lesbos in an inflatable dingy crossing the narrow stretch of water that separates it from mainland Turkey. On the island, he stayed at the Moria refugee camp for seven months where he applied for asylum. He described the conditions at the camp as unsanitary and appalling: no protection against snowy weather, poor sleeping and bathroom facilities with inadequate and poor nutrition. He traveled to Athens upon completion of the interview process for legalization of his status. In 2016, the Greek government approved his application and granted him refugee status which enabled him to secure a permanent job. Though not thoroughly assimilated in his host country, Victor does not intend to relocate to his native Nigeria. ${ }^{18}$

Victor's experience is similar to David Solomon Yekoster's who also sought refugee status in Greece in 2017. Born in Addis Ababa, Ethiopia, David immigrated to Greece through Turkey for socio-political and economic reasons. He noted that though he was unemployed after he finished high school, the low-level insurgency by the Oromo ethnic group and the heavy-handed approach adopted by the Ethiopian government became a major safety concern for him. He also cited the intermittent deadly clashes between political protesters and government troops as a source of anxiety for him. Fearing for his life, he flew to Turkey in 2017 and walked through bushes and forests for four days to the city of Kavala in Greece where he was arrested and detained for ten days; he eventually traveled to Thessaloniki by bus after his release. Unlike other African migrants who traveled to Greece, Yokoster bypassed the refugee camp and traveled to Alexandria where he stayed with a former classmate for three months. He eventually traveled to Athens to apply for refugee status. Though he has work authorization, he remained unemployed. With the new political dispensation in native Ethiopia, Yokoster hopes to return to his home country rather than stay in Greece where he suffers daily humiliation. ${ }^{19}$ While Yokoster left his native Ethiopia for political reasons, other African migrants such as Michelle Thea, a Guinean national, left his country as a result of ethnic clashes between Mandinka and Gbereseh-speakers. Before he departed Guinea, Thea was determined to immigrate to Europe, particularly France or Belgium, where he hoped to acclimatize socially, given his proficiency in French. On the basis of this, he left Guinea for Cotonou, Benin from where he decided to immigrate to Greece through Turkey. He stayed in Turkey for five months before traveling by boat to the Island of Samos in Greece, where he was housed in a refugee camp for a year. He described the conditions at the camp as deplorable and unfit for "human habitation" and further noted that "the food was insufficient and bad while water was 
rationed."20 On a number of occasions, Thea noted that he slept outside the camp because the facilities were insufficient to accommodate the large number of asylum seekers and there were few beds available. In contrast to Okarfo and Yekoster, Thea sought political asylum upon arrival in Greece because he feared political persecution in Guinea though he did not make a strong case in his testimony for such protection. Despite the numerous challenges he experienced in Greece, he noted that he had no intention of returning to his country.

Davy Frank Kubuimana's reason for immigrating to Greece was similar to Thea's. A native of Bujumbura, Burundi, Kubuimana departed his country in 2016 because of deadly clashes between Burundi's main ethnic groups -the Hutus and Tutsis. It should be pointed out that these two ethnic groups have a history of genocidal conflicts as evident in the Rwanda genocide of 1994. Davy left because he saw ominous signs of "genocidal tendencies on the part of the Hutus towards the Tutsis in Burundi;" this forced him to leave "for another country." ${ }^{21}$ In April 2016, he first departed Burundi for the Democratic Republic of Congo where he stayed for six months while he assessed his options. He then traveled to Kampala from Rwanda and flew to Turkey where he stayed for two years. In Turkey, Kubuimana refused to stay in a camp for refugees because he faced lots of racist and degrading treatments in the hands of border patrol agents. He eventually boarded a boat from Turkey to Samos where he applied for asylum. He stayed at the Samos Refugee Camp for six months before his application was approved. In spite of this, he was unable to get a job and remained on the government's assistance program. He hoped to return to Burundi when the political situation improves.

The accounts of these interviewees show that migration to parts of Europe, especially Greece and Italy was not merely driven by economic factors as many scholars, political commentators, and nationalist politicians opine. This point is buttressed by the experience of Alain Chanfort Tezano from Yaoundé, Cameroon. Alain left Cameroon because of his sexual orientation -he described himself as a gay African who lived "in a country that is hostile to that lifestyle and social orientation." He faced threats to his life after he came out as gay because Cameroonian society criminalizes same-sex relationships. In 2016, he flew from Cameroon to Cyprus where he stayed for one year and eight months before traveling to Izmir in Turkey. He stayed in Izmir for three months in a makeshift facility which illegally housed African migrants. He finally traveled 
It is plausible to argue that the hostility of some citizens in host countries towards African migrants has made and continues to make the process of social osmosis arduous and a rugged path to traverse to Samos Refugee Camp in Greece where he stayed for six months before relocating to Athens. $\mathrm{He}$ reached out to the gay community in Athens but only received token assistance from some of its members. Despite this, Alain hopes to permanently reside in Greece and has no intention to return to his hometown of Yaoundé. ${ }^{22}$

Other African immigrants/refugees such as Mohammed Kebbe from Senegal and Keita Vassiriki from Cote d'Ivoire interviewed in Rome adduced multifarious reasons for immigrating to Europe. Kebbe, for example, noted that he departed Senegal because he did not think he had a future in his home country. He lamented the lack of youth employment and poor educational standards in his native Senegal and therefore sought a better future anywhere in Europe. He departed Senegal in 2013 for Libya and eventually arrived in Malta where he spent a year before the Maltese government sent him to Rome in 2016. ${ }^{23}$ Vassiriki, unlike Alain, departed Cote d'Ivoire in 2010 for political reasons. He stated that in 1999 Cote d'Ivoire became embroiled in a political upheaval that brewed for years and resulted in a civil war between President Gbagbo's forces and supporters of his opponent, Alassane Ouattara. Vassiriki who was no fan of former President Gbagbo left Cote d'Ivoire for Burkina Faso from where he traveled to Niger and later to al-Asaba in Libya where he lived for a year. In 2015, Vassiriki traveled by boat to Lampedusa and wound up in Rome in $2016 .^{24}$

The above oral accounts from various African migrants in Greece and Italy show that a range of factors influenced their immigration to Southern Europe in particular.

\section{Conclusion}

It is worth pointing out that Africans seeking refuge and asylum in Europe suffer social and psychological problems. In reinforcing this perspective, Heather Merrill asserts that African refugees and immigrants are classified as not "belonging to" Europe. In her book, Black Spaces: African Diaspora in Italy, she argues that anti-blackness and anti-black racism are visible at immigrant detention centers and shelters across Italy. This is because, Merrill argues, Italy was not ready and willing to be a "country of immigration and port of entry" to the European Union and surrounding countries. In light of Italy's aversion to African migrants, refugees and other economic migrants are categorized 
formal and informal economies of these countries. In other words, African migration is a two-edged sword: the phenomenon deprives the continent of its highly skilled professionals, increases the professional pool of host countries while providing economic security for highly skilled migrants.

All in all, multiple sources, including statistical data and reports from United Nations agencies and interviews, show that even though transcontinental African migration attracts international attention and migrants are used as political pawns in host countries, the African continent regularly receives more migrants from the Middle East and other places in Asia than any other continent. Additionally, Kane and Leedy argue that intracontinental African migration continues to be far more significant and expansive than intercontinental and transnational migration -a reinforcement of the fact that transnational and transcontinental African migration remains peripheral and insignificant relative to global migratory trends.

Finally, based on numerous accounts from interviewees, it is plausible to argue that the hostility of some citizens in host countries towards African migrants has made and continues to make the process of social osmosis arduous and a rugged path to traverse.

\section{Endnotes}

1. Fieldwork for this article was carried out in Greece and Italy in the summer of 2018 and was sponsored by Dr. Margaret Wiedenhoeft, Executive Director of the Center for International Programs at Kalamazoo College.

2. Jeremy Black, The Atlantic Slave Trade in World History, (New York and London: Routledge, 2015); James Walvin, Crossings: Africa, the Americas and the Atlantic Slave Trade, (London: Reaktion Books LTD, 2013); Marcus Rediker, The Slave Ship: A Human History, (New York: Penguin Group, 2007); Lisa Lindsay, Captives as Commodities: The Transatlantic Slave Trade, (New Jersey: Pearson Prentice Hall, 2008).

3. See, Lee Wengraf, Extracting Profit: Imperialism, Neoliberalism, and the New Scramble for Africa, (Chicago: Haymarket Books, 2018); Robert Harms, Africa in Global History with Sources, (New York: W.W. Norton and Company, 2018); Robert O. Collins and James M. Burns, A History of Sub-Saharan Africa, $2^{\text {nd }}$ Edition, (Cambridge: Cambridge University Press, 2014); Richard A. Reid, A History of Modern Africa to the Present, (Oxford: John Wiley \& Sons, Limited, 2012); Collin Legum, Africa Since Independence, (Bloomington and Indianapolis: Indiana University Press, 1999); Georges Nzongola-Ntalaja, The Congo: From Leopold to Kabila: A People's History, (London and New York: Zed Books, 2002); Phyllis M. Martin and Patrick O'Meara, Africa, (Bloomington and Indianapolis: Indiana University Press, 1995).

4. See, John D. Fage and William Tordoff, A History of Africa, $4^{\text {th }}$ Edition, (London and New York: Routledge, 2002); Anders Themnér (ed.), Warlord Democrats in Africa: Ex-Military Leaders and Electoral Politics, (London: Zed Books, 2017).

5. Thomas Benjamin, The Atlantic World: Europeans, Africans, Indians and Their Shared History, 1400-1900, (Cambridge: Cambridge University Press, 2009).

6. Steve Tonah, Mary B. Setrana, and John A. Arthur, Migration and Development in Africa: Trends, Challenges and Policy Implications, (Lanham: Lexington Books, 2017).

7. See, Joseph E. Inikori and Stanley L. Engerman (eds.), The Atlantic Slave Trade, (Durham: Duke University Press, 1992); Patrick Manning, Slavery and African Life, (Cambridge: Cambridge University Press, 
1990); Elizabeth Isichei, A History of African Societies to 1870, (Cambridge: Cambridge University Press, 1997); Alexander Byrd, Captives and Voyagers: Black Migrants Across the Eighteenth-Century British Atlantic World, (Baton Rouge: Louisiana State University Press, 2008); John Thornton, Africa and Africans in the Making of the Atlantic World, 1400-1800, (New York: Cambridge University Press, 1998); Rosanne Marion Adderley, "New Negroes from Africa": Slave Trade Abolition and Free African Settlements in the Nineteenth-Century Caribbean, (Bloomington: Indiana University Press, 2006).

8. See, Tonah, Setrana, and Arthur, Migration and Development in Africa: Trends, Challenges and Policy Implications.

9. See, Abdulaye Kane and Todd H. Leedy (eds.), African Migrations: Patterns and Perspectives, (Bloomington and Indianapolis: Indiana University Press, 2013).

10. Alusine Jalloh, Muslim Fula Business Elites and Politics in Postcolonial Sierra Leone, (New York: Rochester University Press, 2017).

11. "About ECOWAS," West Africa Agrofood, retrieved November 10, 2018, from https://www.agrofood-westafrica.com/agrofood-westafrica-ecowas.html.

12. "SADC - Southern African Development Community," UNECA, retrieved November 11, 2018, from https://www.uneca.org/oria/pages/sadc-southern-african-development-community; "COMESA - Common Market for Eastern and Southern Africa," UNECA, retrieved November 11, 2018, from https://www. uneca.org/oria/pages/comesa-common-market-eastern-and-southern-Africa; "East African Community," retrieved from November 11, 2018, from http://www.eac.int/.

13. Abdulaye and Leedy, African Migrations: Patterns and Perspectives; Marda Mustapha and Joseph J. Bangura, Democratization and Human Security in Postwar Sierra Leone, (New York: Palgrave Macmillan, 2015).

14. Pauline Ada Uwakeh, Jerono P. Rotich, and Comfort O. Okpala (eds.), Engaging the Diaspora: Migration and African Families, (Lanham: Lexington Books, 2014).

15. "Desperate Journeys," The UN Refugee Agency, retrieved November 1, 2018, from http://www.unhcr. org/desperatejourneys.

16. "Desperate Journeys," The UN Refugee Agency.

17. "Interviewee A" interviewed by Joseph J. Bangura, Athens, Greece (July 13, 2018). The interviewee asked that her name should not be used in this interview for fear of political repercussion. Other interviewees gave explicit permission for their names to be used. All interviews and translations are mine and cannot be used without explicit permission from the author.

18. Victor Okarfo interviewed by Joseph J. Bangura, Kypseli, Athens, Greece (July 13, 2018).

19. David Solomon Yekoster interviewed by Joseph J. Bangura, Kypseli, Athens, Greece (July 14, 2018).

20. Michelle Thea interviewed by Joseph J. Bangura, Plateia Amerikis, Athens, Greece (July 14, 2018).

21. Davy Frank Kutubuimana interviewed by Joseph J. Bangura, Plateia Amerikis, Athens, Greece (July 14, 2018).

22. Alain Chanfort Tezano interviewed by Joseph J. Bangura, CARITAS, Athens, Greece (July 17, 2018).

23. Mohammed Kebbe interviewed by Joseph J. Bangura, Casa Scabrini, Rome, Italy (July 20, 2018).

24. Keita Vassiriki interviewed by Joseph J. Bangura, Casa Scabrini, Rome, Italy (July 20, 2018).

25. Heather Merrill, Black Spaces: African Diaspora in Italy, (New York: Routledge, 2018).

26. "Desperate Journeys," The UN Refugee Agency. 
